\title{
PEMODELAN MEKANISME UMPAN BALIK REAKTIVITAS PADA SIMULATOR REAKTOR KARTINI
}

\author{
Anisa Fitri ${ }^{1 *}$, Adi Abimanyu' ${ }^{1}$, Sutanto $^{1}$ \\ ${ }^{1}$ Sekolah Tinggi Teknologi Nuklir, Yogyakarta, Indonesia \\ *Corresponding author: annisafitriemc@gmail.com
}

\begin{abstract}
ABSTRAK
PEMODELAN MEKANISME UMPAN BALIK REAKTIVITAS PADA SIMULATOR REAKTOR KARTINI. Pengendalian reaktor dilakukan dengan beberapa tahapan seperti mengubah jumlah atau posisi bahan bakar, mengubah moderator atau reflektor serta menambah atau mengurangi bahan penyerap neutron di dalam teras reaktor. Ketiga tahapan tersebut mempengaruhi daya reaktor melalui perubahan nilai reaktivitas yang dikenal sebagai efek umpan balik reaktivitas. Untuk mengetahui efek umpan balik reaktivitas terhadap daya reaktor maka dilakukan Pemodelan Mekanisme Umpan Balik Reaktivitas pada Simulator Reaktor Kartini berbasis LabVIEW. Nilai reaktivitas bahan bakar dan pendingin didapatkan dari data operasi reaktor Kartini mengenai suhu bahan bakar dan pendingin terhadap daya reaktor. Nilai reaktivitas bahan penyerap neutron didapatkan melalui konversi posisi batang kendali penyerap neutron menjadi reaktivitas dengan memanfaatkan data kalibrasi terakhir batang kendali reaktor Kartini. Ketiga nilai reaktivitas tersebut dijumlahkan dan dihitung dalam persamaan kinetika reaktor titik, dan dikonversi menjadi besaran daya reaktor. Efek umpan balik akan mengubah parameter dalam persamaan kinetika, terutama pada nilai reaktivitas total. Model umpan balik reaktivitas telah berhasil dibuat dan menghasilkan daya konstan. Model umpan balik reaktivitas sudah dimasukkan dalam simulator reaktor Kartini. Namun demikian hasil perhitungan daya belum divalidasi dengan daya reaktor Kartini.
\end{abstract}

Kata kunci: pemodelan reaktor titik, simulator reaktor Kartini, umpan balik reaktivitas

\section{ABSTRACT}

MODELING REACTIVITY FEEDBACK MECHANISM OF KARTINI REACTOR SIMULATOR. Reactor control is carried out by several methods such as changing the amount or position of fuel, moderator or reflector and adding or reducing the neutron absorber material inside the reactor core. All three methods affect the reactor power through the reactivity value change, known as feedback reactivity effect. To understand the effect of reactivity feedback on reactor power, Reactivity Feedback Mechanism Modeling of Kartini Reactor Simulator based on LabVIEW is done. Fuel and coolant reactivity values are derived from Kartini reactor operating data on fuel and coolant temperatures to reactor power. The reactivity value of the neutron absorber was obtained by converting the neutron absorber control rod position into reactivity by utilizing the last calibration data of the Kartini reactor control rod. All three reactivity values are summed and calculated in the point reactor kinetics equation, and converted to reactor power quantities. Feedback effect will change kinetic equation parameters, especially at the total reactivity value. At the beginning of the operation reactivity value increase to positive reactivity given by the displacement of the control rod. Reactivity feedback has been successfully created. After the control rod stops moving, the total reactivity value is constant for a moment to produce a certain power value and produces an increasing coolant and fuel temperature. This increase in temperature provides a negative reactivity effect resulting reduction in total reactivity so that the final value becomes zero and reactor power is found in constant conditions.

Key words: point reactor modeling, simulator Kartini reactor, reactivity feedback

\section{PENDAHULUAN}

Reaktor Kartini berada di Pusat Sains dan Teknologi Akselerator-Badan Tenaga
Nuklir Nasional (PSTA-BATAN) Yogyakarta, dibangun pada akhir tahun 1974 oleh tenaga ahli BATAN dengan tujuan utama sebagai sarana penelitian, produksi isotop, pendidikan 
dan pelatihan kader-kader dalam bidang reaktor. Reaktor Kartini dirancang dengan tipe Training Reseach \& Isotope Production General Atomic (TRIGA) Mark II dan memiliki kapasitas daya $250 \mathrm{~kW}$, dan mencapai kondisi kritis untuk pertama kali pada tanggal 25 Januari 1979. Hingga saat ini operasi Reaktor Kartini hanya diizinkan pada tingkat daya $100 \mathrm{~kW}$ [1].

Mengingat cakupan aplikasi yang begitu luas, reaktor Kartini dirancang dengan Sistem Instrumentasi dan Kendali (SIK) yang berkembang. Hal ini bertujuan mencapai sasaran jangka panjang yang mendudukan operator sebagai pengamat, pengoptimasi dan manajer dalam keadaan normal ataupun kecelakaan[2]. Salah satu aspek yang dikembangkan dalam SIK reaktor adalah sistem pengendalian reaktor. Sistem pengendalian reaktor adalah sarana untuk mengendalikan proses reaksi pembelahan inti yang terjadi di dalam teras reaktor. Sehingga reaktor dapat dioperasikan mulai dari kondisi subkritik, kemudian dengan menaikkan dan mempertahankan daya reaktor, serta menurunkan dan menghentikan operasi reaktor. Pengendalian reaktor dilakukan dengan beberapa tahapan seperti mengubah jumlah atau posisi bahan bakar, mengubah moderator atau reflektor serta menambah atau mengurangi bahan penyerap neutron yang dikenal sebagai batang kendali di dalam teras reaktor [3].

Secara umum pengendalian reaktor dilakukan dengan mengatur posisi batang kendali sedemikian rupa sehingga didapatkan tingkat daya yang dikehendaki [4]. Tingkat daya reaktor ditentukan oleh perilaku densitas neutron dan konsentrasi perkusor neutron kasip terhadap waktu (time-dependent). Untuk memahami fluktuasi daya yang dialami reaktor, maka dapat dilakuakan pemodelan persamaan kinetika reaktor titik yang merupakan sistem persamaan diferensial densitas neutron dan konsentrasi prekusor neutron kasip. Dimana nilai daya yang dihasilkan sangat tergantung pada waktu dan nilai reaktivitas [5].

Perubahan suhu yang mencakup suhu bahan bakar dan pendingin memberikan nilai reaktivitas, yang secara langsung mempengaruhi nilai densitas neutron. Sehingga secara matematis nilai tersebut memiliki pengaruh yang cukup besar terhadap perubahan nilai daya reaktor. Perubahan reaktivitas semacam ini disebut dengan efek umpan balik re- aktivitas. Sehingga nilai reaktivitas reaktor didapatkan dari hasil penjumlahan dari reaktivitas yang diberikan oleh batang kendali dan umpan balik reaktivitas [6]. Untuk memahami efek umpan balik reaktivitas maka dilakukan penelelitian terkait pemodelan mekanisme umpan balik reaktivitas pada reaktor Kartini dengan menggunakan perangkat lunak LabVIEW.

\section{LANDASAN TEORI}

\section{Kinetika Reaktor}

Pemodelan kinetika titik diperoleh ketika distribusi spasial fluks neutron diabaikan dan hanya memperhatikan perilaku terhadap waktu. Metode Taylor digunakan sebagai solusi perhitungan densitas neutron [7]. Perhitungan densitas neutron diselesaikan dengan Persamaan (1) dan (2).

$$
\begin{gathered}
N(t+h)=N(t)+h\left[\frac{\rho(t)-\beta}{\Lambda}\right] n+h \sum_{i=1}^{6} \lambda_{i} C_{i} \\
C i(t+h)=C i(t)+h \frac{\beta}{\Lambda} n+h \lambda_{i} C_{\bar{i}}
\end{gathered}
$$

dengan,

$n(t) \quad=$ rapat neutron pada saat $\mathrm{t}$ (neutron $/ \mathrm{cm}^{3}$ )

$C_{i}(t)=$ konsentrasi precursor neutron kasip kelompok ke-i

$\rho(t) \quad=$ reaktivitas total teras pada saat $\mathrm{t}$

$\beta_{i} \quad=$ fraksi neutron kasip kelompok ke-i

$\beta \quad=$ fraksi kelompok neutron kasip efektif

$\lambda_{\bar{i}} \quad=$ konstanta peluruhan prekursor neutron kasip kelompok ke-i (detik $\left.{ }^{-1}\right)$

\section{Umpan Balik Reaktivitas}

Reaktor nuklir dinamik berkaitan dengan daya reaktor sesaat, dimana daya berubah akibat perubahan umpan balik reaktivitas. Umpan balik reaktivitas memiliki peran penting dalam perilaku reaktor secara keseluruhan [8]. Pada operasi reaktor nuklir, populasi neutron dalam jumlah yang cukup besar akan menghasilkan perubahan suhu yang dapat mengubah nilai reaktivitas atau umpan balik reaktivitas [9]. Salah satu penyebab umpan balik reaktivitas adalah perubahan suhu, 
dengan koefisien reaktivitas suhu $\left(\alpha_{T}\right)$ didefinisikan seperti pada Persamaan (3) [10].

$$
\alpha_{T}=\frac{d \rho}{d T}
$$

dengan,

$\mathrm{d}^{\rho} \quad=$ perubahan nilai reaktivitas

$\mathrm{dT}=$ perubahan suhu

Reaktivitas $\rho(t)$ dikenal sebagai hasil penjumlahan dari reaktivitas yang diberikan kepada reaktor secara eksternal melalui batang kendali $\delta \rho_{\text {ext }}(t)$ dan reaktivitas feedback $\delta \rho_{f}(t)$ yang didapatkan melalui faktor internal reaktor. Secara matematis pernyataan tersebut dituliskan seperti pada Persamaan (4).

$$
\rho(t)=\delta \rho_{\text {ext }}(t)+\delta \rho_{f}(P)
$$

dengan,

$\delta \rho \quad=$ diferensial dari nilai kesetimbangan .

Blok diagram percobaan reaktor dengan reaktivitas feedback ditunjukkan pada Gambar 1 [11].

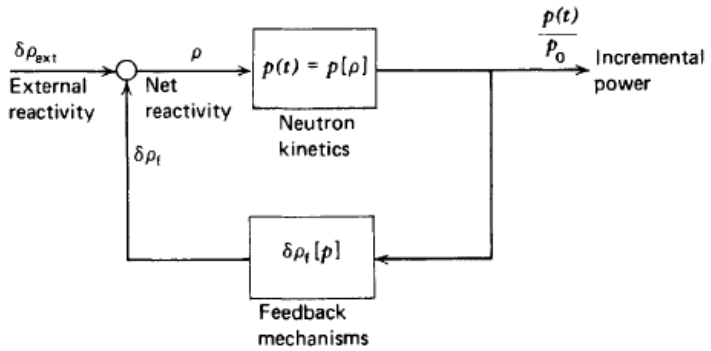

Gambar. 1. Mekanisme umpan balik

\section{Konversi Perubahan Posisi}

Sebuah batang kendali yang dimasukan ke dalam teras reaktor dengan jarak $x$, akan memberikan perubahan reaktivitas sebesar $\Delta \rho(x)$ berpengaruh terhadap nilai daya reaktor. Oleh karena nilai perpindahan batang kendali harus dikonversi menjadi nilai perubahan reaktivitas agar perubahan daya dapat dikendalikan dengan menggunakan perpindahan batang kendali. Untuk melakukan konversi tersebut dapat digunakan Persamaan (5) [12].

$$
\Delta \rho(x)=\Delta \rho(H)\left(\frac{x}{H}-\frac{1}{2 \pi} \sin \frac{2 \pi x}{H}\right)
$$

dengan

$$
\begin{aligned}
& \Delta \rho(x)=\text { perubahan reaktivitas }(\$) \\
& \Delta \rho(H)=\text { perubahan reaktivitas akibat insersi } \\
& \quad \text { full batang kendali } \\
& \mathrm{H} \quad=\text { tinggi total teras reaktor }(\mathrm{cm})
\end{aligned}
$$

\section{Konversi Daya}

Perhitungan kinetika reaktor dengan menggunakan Persamaan (1) dan (2) menghasilkan nilai densitas neutron yang membangkitkan nilai daya reaktor dengan Persamaan (6) [3].

$$
P=\frac{\Sigma_{f} \phi V_{r}}{3.125 \times 10^{10}}
$$

dengan

$$
\begin{array}{ll}
\mathrm{P} & =\text { Daya reaktor (watt) } \\
\Sigma_{f} & =\text { tampang lintang makroskopik }\left(\mathrm{cm}^{-1}\right) \\
\phi & \left.=\text { fluks neutron (neutron } / \mathrm{cm}^{2} . \operatorname{detik}\right) \\
V_{r} & =\text { volume teras reaktor }\left(\mathrm{cm}^{3}\right)
\end{array}
$$

\section{METODE PENELITIAN}

Metode yang dilakukan pada penelitian ini secara umum adalah melakukan studi pustaka, pengambilan data pembuatan model, analisis kesalahan dan perbaikan jika diperlukan, serta pengambilan data. Pemodelan sistem secara umum dibagi menjadi beberapa bagian tahap, yaitu:

1. Pembuatan model simulasi batang kendali, dibuat untuk menggerakan dan memberikan nilai reaktivitas batang kendali.

2. Pembuatan program kinetika reaktor dibuat untuk menghitung densitas neutron.

3. Implementasi model pada program kinetika reaktor dilakukan untuk memberikan nilai reaktivitas batang kendali pada perhitungan kinetika reaktor.

4. Pemrograman persamaan umpan balik dibuat dengan memberikan nilai reaktivitas suhu bahan bakar dan pendingin. Dan kemudian dijumlahkan dengan reaktivitas bahan bakar, dan hasilnya digunakan untuk perhitungan densitas neutron. 
5. Pembuatan proses perhitungan daya untuk melihat pengaruh reaktivitas terhadap daya.

\section{Pemodelan umpan balik reaktivitas}

Pemodelan dimulai dengan membuat model penghasil tegangan motor penggerak batang kendali dalam sebuah sub VI (virtual instrument) dengan tujuan menyederhanakan pembuatan program. Sub VI dapat dilihat pada Gambar 2.

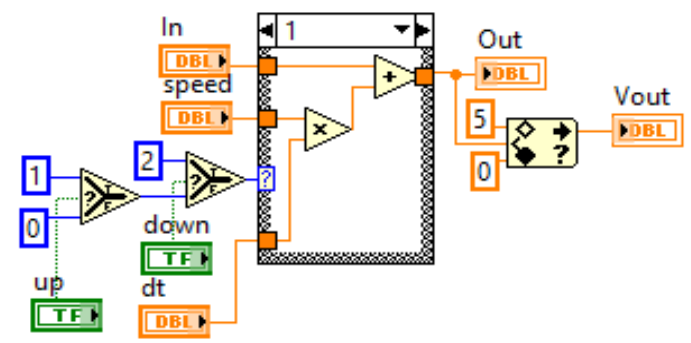

Gambar. 2. Program penghasil tegangan penggerak batang kendali

Setelah model penghasil tegangan berhasil dibuat, tegangan kemudian dikonversi menjadi posisi dan reaktivitas batang kendali. Konversi dilakukan seperti Gambar 3.

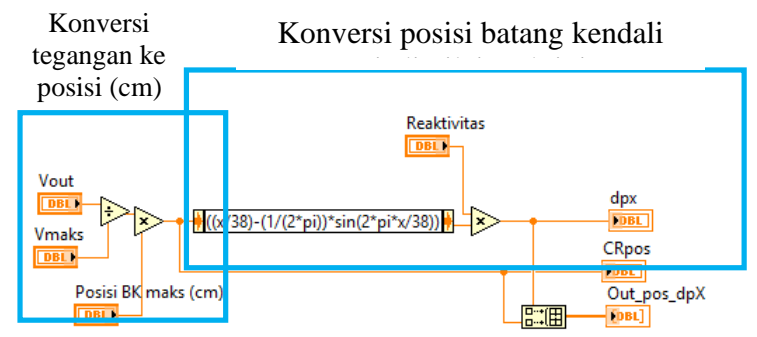

Gambar. 3. Konversi perubahan batang kendali ke reaktivitas

Setelah itu dilakukan pembuatan program kinetika reaktor dilakukan dengan menggunakan perangkat lunak LabVIEW 2015. Langkah pembuatan program kinetika reaktor adalah sebagai berikut [5].

1. Menentukan nilai awal untuk densitas neutron $\left(N_{0}\right)$, konsentrasi awal precursor neutron $\left(C_{0}\right)$, reaktivitas awal $\left(\rho_{0}\right)$, fraksi neutron kasip $(\beta)$, waktu generasi neutron kasip $\Lambda$, konstanta peluruhan prekursor $(\lambda)$.

2. Menentukan increment waktu, $h$.

3. Menghitung densitas neutron untuk waktu $(t+h)$ dengan mengalikan densitas neutron sebelumnya dengan increment waktu, $h$, ditambah dengan densitas neutron pada saat $t$, seperti pada Persamaan (1).

4. Menghitung konsentrasi prekursor neutron kasip untuk waktu $(t+h)$ dengan mengalikan konsentrasi prekursor neutron kasip sebelumnya dengan increment waktu, $h$, ditambah dengan konsentrasi prekursor neutron kasip pada saat $t$, seperti pada Persamaan (2).

Setelah program kinetika berhasil dibuat maka dilakukan implementasi batang kendali dan validasi hasil terhadap hasil pemodelan. Hasil pemodelan dapat dilihat pada Gambar 4. Program kinetika dimasukan secara langsung pada while loop, sehingga hasil perhitungan kinetika yang diberikan input melalui model batang kendali dapat direpesentasikan secara continue.

Setelah model simulator reaktor Kartini yang dikendalikan tanpa pengaruh suhu berhasil dilakukan, maka hasil perhitungan daya dari model tersebut digunakan untuk menghitung daya reaktor. Suhu didapatkan berdasarkan hasil operasi reaktor Kartini, seperti Tabel 1. Selain suhu pendingin, nilai densitas neutron juga dipengaruhi oleh suhu bahan bakar. Berdasarkan hasil operasi reaktor Kartini didapatkan data seperti pada Tabel 2.

\begin{tabular}{rr} 
Tabel. 1. Data suhu pendingin \\
$\begin{array}{c}\text { Suhu pendingin } \\
\left({ }^{\circ} \mathrm{C}\right)\end{array}$ & $\begin{array}{c}\text { Daya } \\
(\mathrm{kW})\end{array}$ \\
\hline 26,3 & 0.001 \\
26,5 & 1,860 \\
26,7 & 4,200 \\
26,8 & 71,900 \\
26,8 & 91,100 \\
\hline
\end{tabular}

Tabel. 2. Data suhu bahan bakar

\begin{tabular}{cr}
\hline $\begin{array}{c}\text { Suhu pendingin } \\
\left({ }^{\circ} \mathrm{C}\right)\end{array}$ & $\begin{array}{c}\text { Daya } \\
(\mathrm{kW})\end{array}$ \\
\hline 30,25586 & 0,00 \\
30,25464 & 1,86 \\
30,86708 & 2,90 \\
31,87643 & 4,20 \\
32,99598 & 4,90 \\
33,03258 & 61,80 \\
34,19280 & 71,90 \\
35,35627 & 84,20 \\
36,54235 & 91,10 \\
\hline
\end{tabular}


Pemodelan umpan balik reaktivitas dalam penelilitan ini dilakukan secara sederhana, dan belum memperhatikan perhitungan termal hidrolik. Data pada Tabel 1 dan 2 digrafikkan dan didapatkan fungsi suhu dan bahan bakar yang digunakan untuk menghasilkan reaktivitas suhu. Reaktivitas suhu bahan bakar dan pendingin dihitung dengan Persamaan (3). Setelah dihasilkan reaktivitas suhu, dilakukan kalkulasi seperti pada Gambar 5.

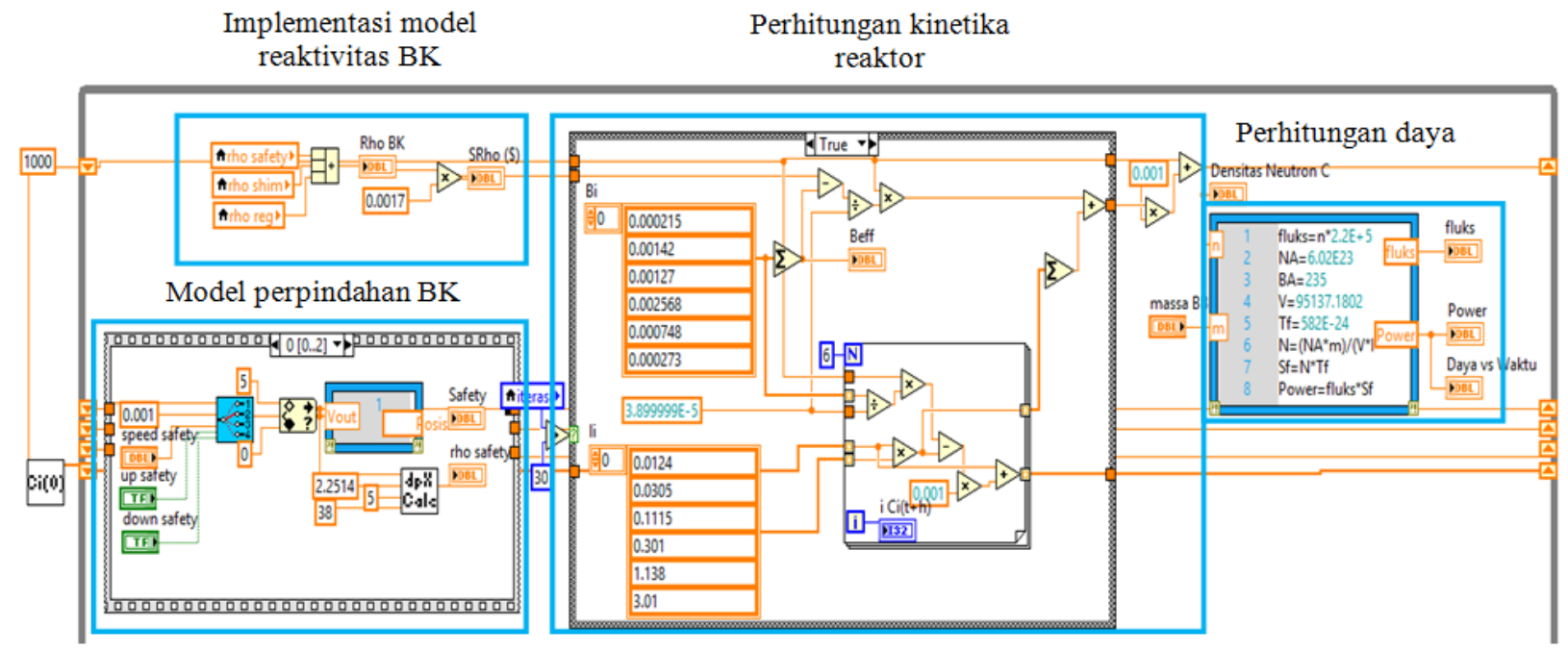

Gambar. 5. Program kinetika reaktor dalam bahasa LabVIEW

Pembuatan program mekanisme umpan balik dilakukan dengan menggunakan data operasi reaktor Kartini. Data tersebut diolah dan dihitung untuk mendapatkan nilai persamaan linier dari suhu bahan bakar dan pendingin terhadap daya reaktor. Tahapan pemodelanya terdiri dari pemodelan

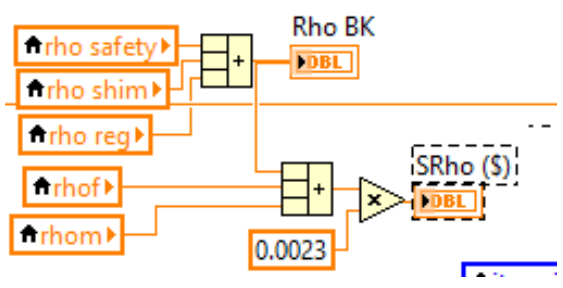

Gambar. 4. Kalkulasi reaktivitas batang kendali dan suhu

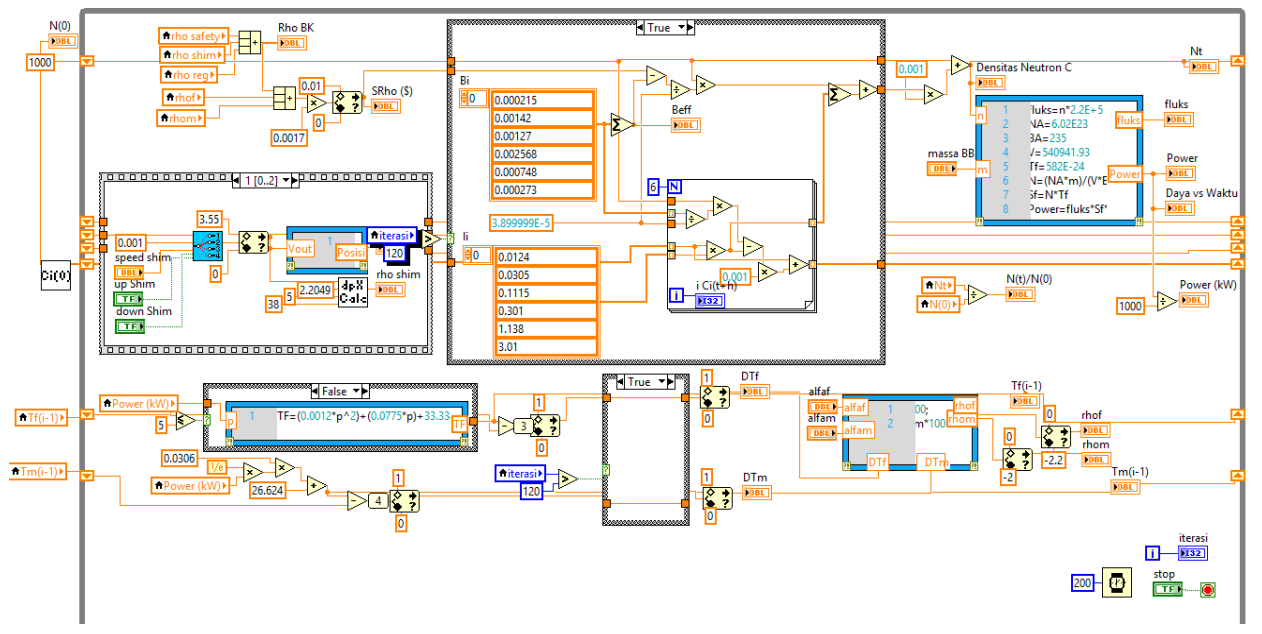

Gambar. 6. Program umpan balik reaktivitas 


\section{HASIL DAN PEMBAHASAN}

\section{Validasi program kinetika reaktor}

Validasi program kinetika dilakukan dengan membandingkan grafik densitas neutron hasil perhitungan program pada Gambar 8 dengan grafik penelitian pemrograman kinetika reaktor pada Gambar 7.

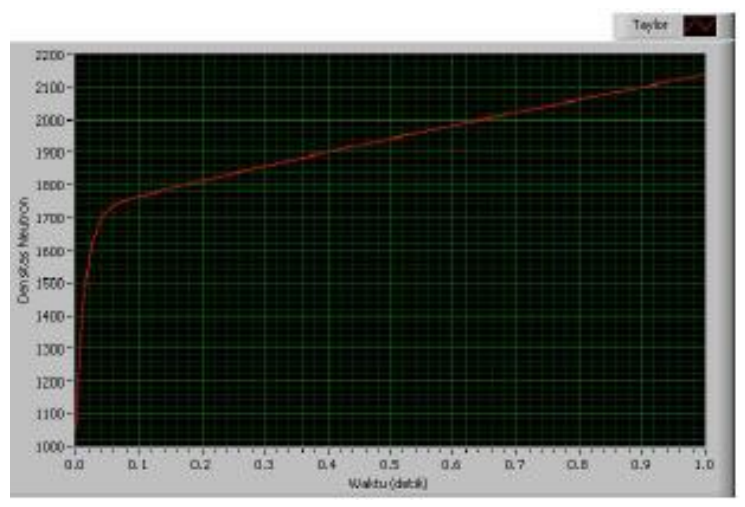

Gambar. 7. Hubungan densitas neutron terhadap waktu penelitian kinetika reaktor

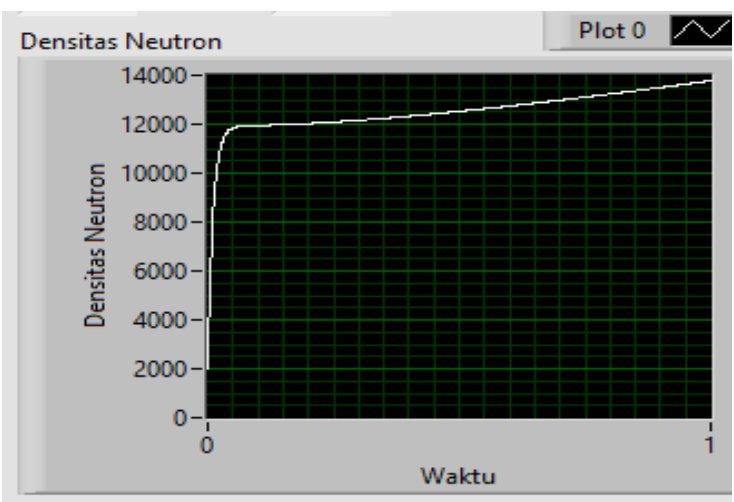

Gambar. 8. Hubungan densitas neutron terhadap waktu penelitian umpan balik reaktivitas

Hasil perbandingan menunjukkan bahwa program kinetika telah sesuai dengan penelitian sebelumnya. Sehingga penelitian mengenai simulator reaktor Kartini dapat dilanjutkan dengan menggunakan umpan balik reaktivitas.

\section{Efek umpan balik suhu negatif pada populasi neutron}

Tampilan hasil pemodelan pada program umpan balik reaktivitas dapat dilihat pada Gambar 9. Tampilan terdiri dari tiga buah model penampil batang kendali yang terdiri dari safety, shim dan regulating. Selain itu juga terdapat tampilan grafik nilai setiap reaktivitas dan daya reaktor.

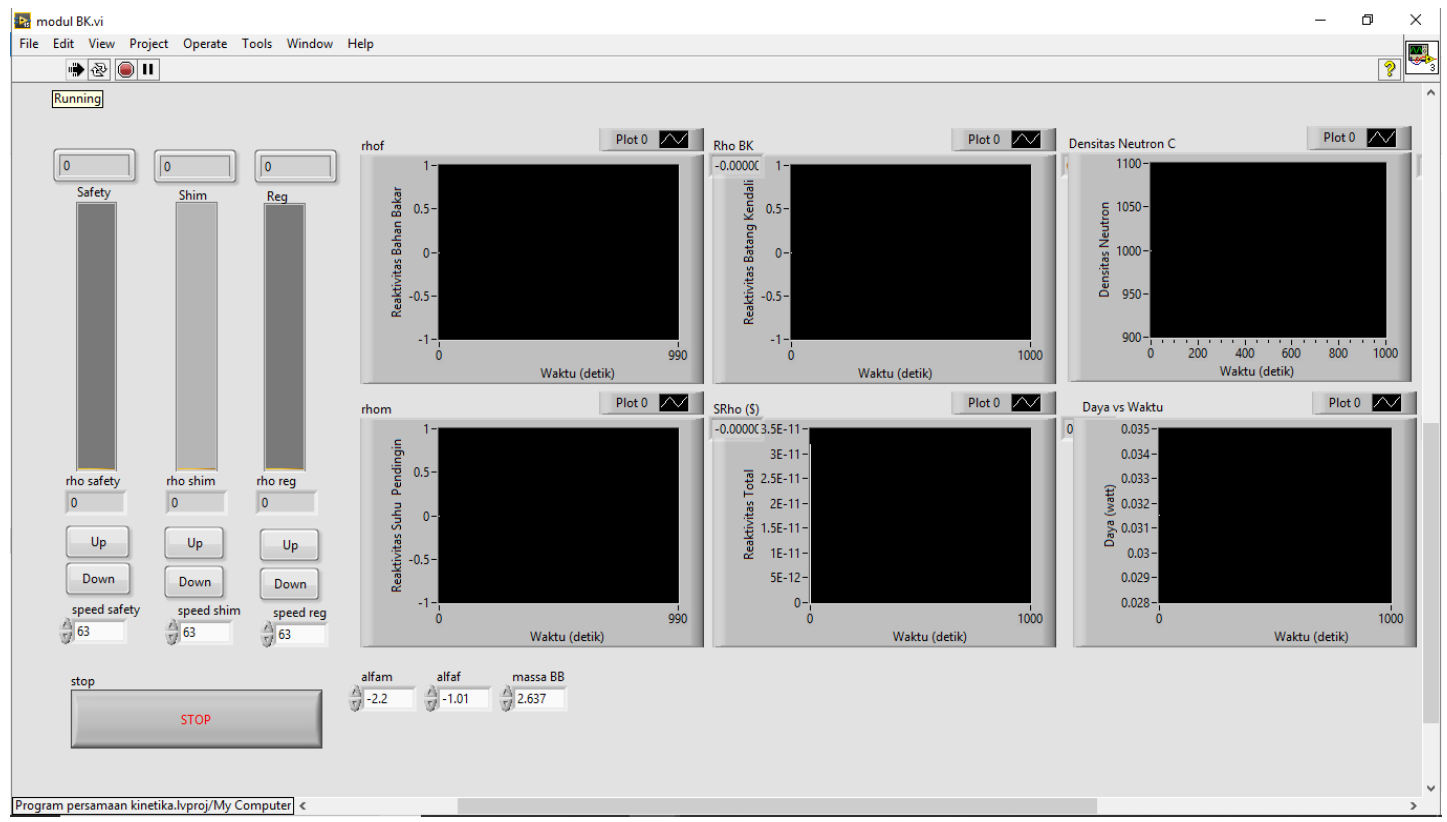

Gambar. 9. Tampilan model umpan balik reaktvitas 
Ketika umpan balik reaktivitas belum diberikan, maka dalam perhitungan kinetika hanya menerima masukan dari reaktivitas batang kendali seperti Gambar 10.

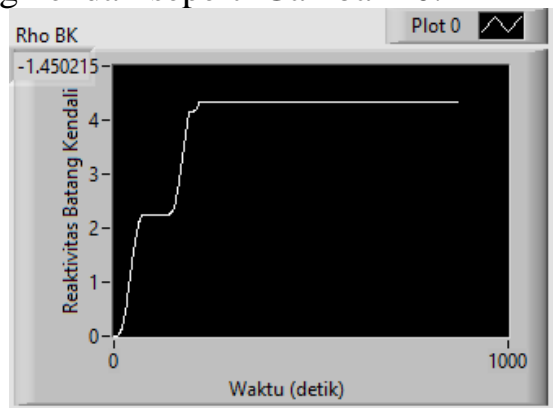

Gambar. 10. Reaktivitas batang kendali

Sehingga nilai densitas neutron bertambah secara continue dan menghasilkan grafik daya reaktor seperti Gambar 11.

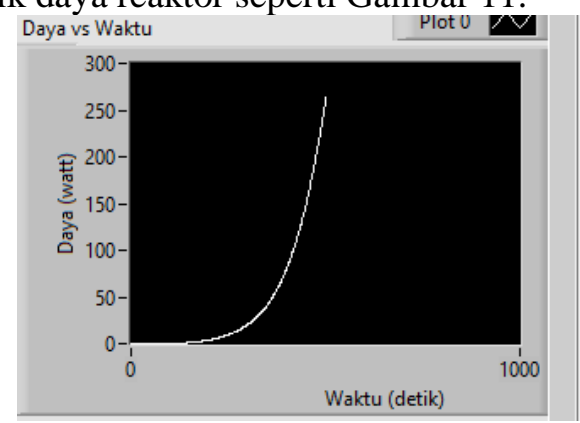

Gambar. 11. Hasil perhitungan daya reaktor tanpa umpan balik

Untuk perhitungan densitas neutron dengan pengaruh umpan balik dapat dilihat nilai reaktivitas suhu pada Gambar 12.

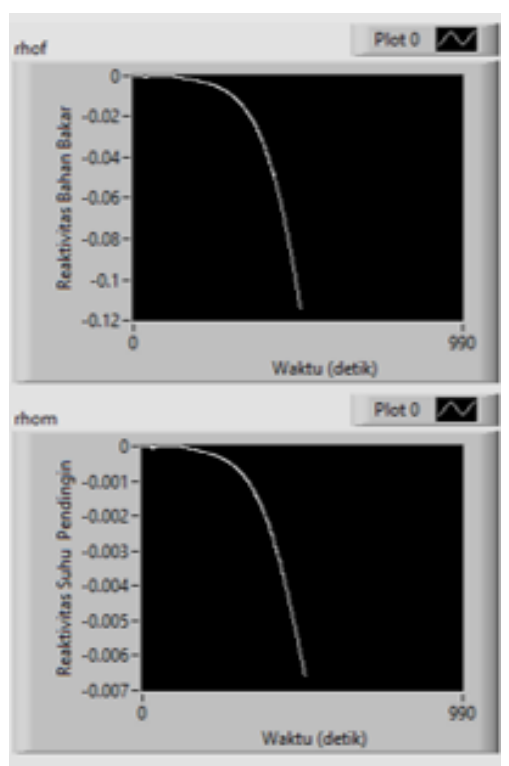

Gambar. 12. Reaktivitas suhu bahan bakar dan pendingin
Dengan reaktivitas suhu yang bernilai positif maka reaktivitas total mengalami pengurangan seperti Gambar 13.

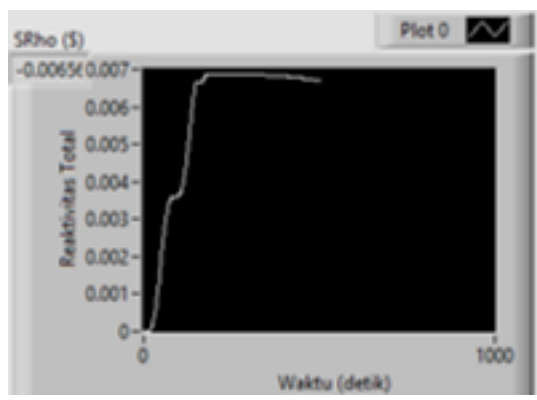

Gambar. 13. Pengaruh reaktivitas suhu terhadap reaktivitas total

Dengan adanya pengurangan pada reaktivitas total maka perhitungan densitas neutron ikut berkurang hingga dihasilkan nilai densitas neutron yang konstan. Nilai densitas neutron yang konstan menghasilkan daya reaktor yang konstan seperti pada Gambar 14.

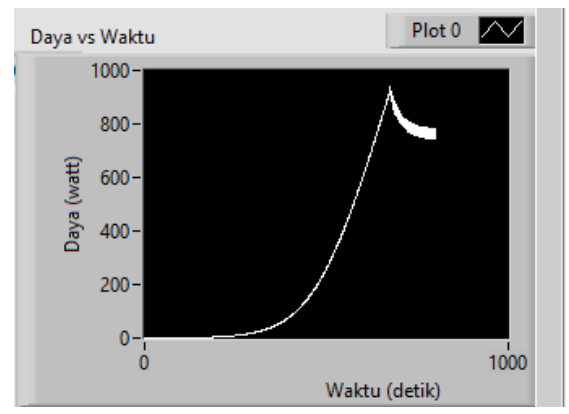

Gambar. 14. Hasil perhitungan daya reaktor dengan umpan balik

Untuk melakukan validasi program dengan dan tanpa umpan balik dilakukan komparasi antara hasil penelitian dan teori. Gambar 15 merupakan teori dalam [13].

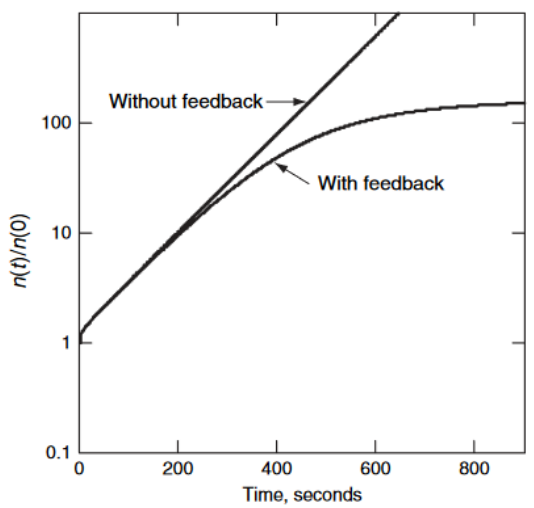

Gambar. 15. Grafik populasi neutron terhadap umpan balik berdasarkan teori 
Untuk grafik populasi densitas neutron terhadap umpan balik dalam penelitian ini dapat dilihat pada Gambar 16.

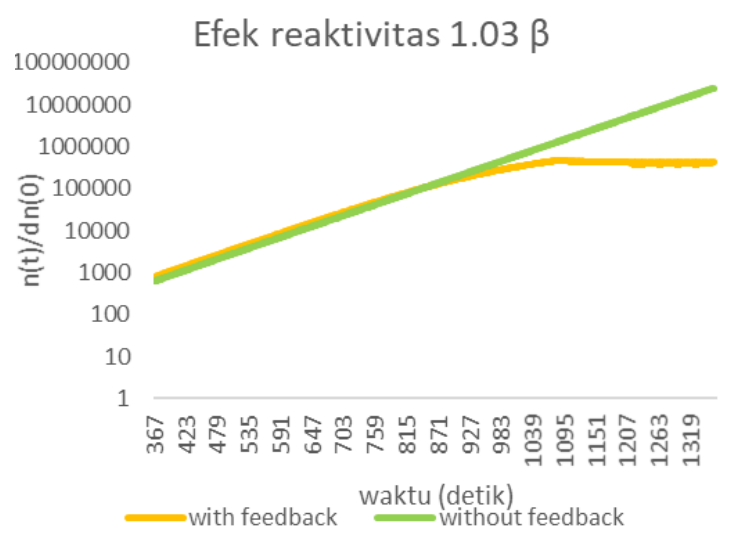

Gambar. 16. Grafik populasi neutron terhadap umpan balik hasil penelitian

\section{KESIMPULAN}

Model umpan balik reaktivitas sudah dimasukkan dalam simulator reaktor Kartini, namun belum dilakukan validasi terhadap daya reaktor Kartini. Berdasarkan penelitian dapat disimpulkan bahwa umpan balik reaktivitas memberikan efek pengurangan terhadap nilai reaktivitas total dan hasil populasi densitas neutron terhadap umpan balik dari pemodelan ini sudah memiliki trend yang sesuai dengan teori.

\section{DAFTAR PUSTAKA}

1. T. Suhaemi, D. Dj. Djen, K. Itjeu, S. Johnny, and Setyono, "Evaluasi Keselamatan Reaktor Kartini ditinjau dari Desain Sistem Instrumentasi," Pros. Present. Ilm. Teknol. Keselam. Nukl. VIII, Feb. 2003.

2. Tim Upgrading Reaktor Kartini, Buku Petunjuk Operasi dan Perawatan Sistem Instrumentasi dan Kendali Reaktor
Kartini. Yogyakarta: Badan Tenaga Nuklir Nasional, 1993.

3. Syarip, Pengenalan Kinetika dan Pengendalian Reaktor Nuklir. Yogyakarta: Badan Tenaga Nuklir Nasional, 2001.

4. Tim LAK Reaktor Kartini, "Laporan Analisis Keselamatan (LAK) Reaktor Kartini Revisi 8 Tahun 2017." PSTABATAN, 2017.

5. A. Cahyono, D. Handoyo, K. Handono, and S. T. Prasaja, "Pemrograman Persamaan Kinetika Reaktor Titik dengan LabView," Prima Apl. Dan Rekayasa Dalam Bid. Iptek Nukl., vol. 9, no. 1, 2012.

6. Y. Oka, Nuclear Reactor Kinetics and Plant Control. Tokyo: Springer Japan, 2013.

7. D. McMahon and A. Pierson, "A Taylor Series Solution of The Reactor Point Kinetics Equations," Dep. Nucl. Saf. Anal., 2008

8. A. Arafa, H. I. Saleh, and N. Ashoub, "Design and implementation progress of multi-purpose simulator for nuclear research reactor using LabVIEW," Kerntechnik, vol. 80, no. 5, pp. 454-464, Oct. 2015.

9. W. M. Stacey, Nuclear Reactor Physics. Canada, 2001.

10. J. K. Shultis, Fundamentals of Nuclear Science and Engineering. New York, 2002.

11. James J. Dedurstadt and Louis J. Hamilton, Nuclear Reactor Analysis.pdf. New York: JHON WILEY \& SONS, Inc., 1976.

12. H. Anglart, Applied Reactor Technology. Nuclear Reactor Technology Division Department of Energy Technology: KTH Royal Institute of Technology, 2011

13. E. E. Lewis, Fundamentals of Nuclear Reactor Physics. Elsevier, 2008. 